
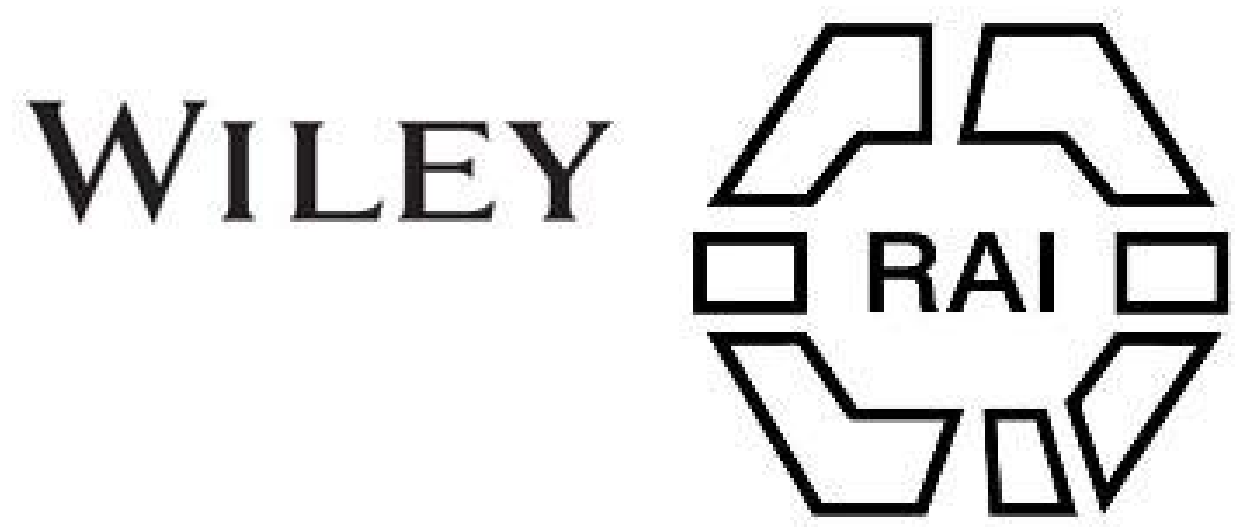

\title{
31. Maori Forgeries.
}

Author(s): J. Edge-Partington

Source: Man, Vol. 10 (1910), pp. 54-55

Published by: Royal Anthropological Institute of Great Britain and Ireland

Stable URL: http://www.jstor.org/stable/2787993

Accessed: 27-06-2016 02:30 UTC

Your use of the JSTOR archive indicates your acceptance of the Terms \& Conditions of Use, available at

http://about.jstor.org/terms

JSTOR is a not-for-profit service that helps scholars, researchers, and students discover, use, and build upon a wide range of content in a trusted digital archive. We use information technology and tools to increase productivity and facilitate new forms of scholarship. For more information about JSTOR, please contact support@jstor.org.

Wiley, Royal Anthropological Institute of Great Britain and Ireland are collaborating with JSTOR to digitize, preserve and extend access to Man 


\section{New Zealand.}

\section{Maori Forgeries. By J. Edge-Partington.}

Since my note on Maori forgeries appeared in MAN $(1909,31)$ I have received two very important communications on this subject, one from Professor Andree, of Munich, confirming my statement with regard to the manufacture of greenstone objects in Germany, and drawing my attention to a visit he made to the factory, described by him in Zeitschrift für Ethnologie, Heft 6, 1907, p. 943. I append a translation of part of this article, but would refer those who take an interest in this question to the original, since the whole is extremely interesting and important:-

"I had heard that the lapidaries of Oberstein and Idar manufactured objects of New Zealand jade, and, moreover, produced extraordinarily accurate copies of the old Maori weapons and ornaments.

"In order to investigate the matter, in the summer of 1907 I visited the pretty little localities in the Nahe valley (on the Bingerbrück-Metz line), in Birkenfeld, an outlying province of Oldenburg, where a large number of lapidaries are engaged in the cutting of hard stones. . . . The hardest material which is worked there is New Zealand jade, the cutting, grinding, and polishing of which is, however, relatively easy of accomplishment.

"Articles which a Maori never could have manufactured, at the expense of any labour, such as goblets, cigar cases, bowls, coffee cups, of jade, as well as ornaments of the most varied description, are to be seen in the Gewerbeballe; but such things were of less importance to me than the imitations of Maori weapons, 'Tiki, Mere, and ornaments, which had also been made in Idar. The principal firm is that of Jakob Wild, who most courteously showed me his method of manufacture, into the technicalities of which I will not enter. I must make it clear that there is no question here of forgeries; the manufacturer quite openly advertises them as his own work, copies of genuine originals, and sells them as such.

"It must be noted that these objects are mostly made in response to commissions received from England, and are also sent direct to New Zealand. Here they are sold to globe-trotters at a high price; or even are put on the market as genuine Tiki, \&c., and so, as I know from actual experience, find their way into Ethnographical Museums. . . . These Idar facsimiles are absolutely exact copies of the originals; at least I could perceive no difference, though such might be apparent to an expert after a closer comparison. The material is genuine, the forms are exact reproductions of the original antiques, and the polish is equally good."

The other communication was from Mr. Hamilton, the Director of the Dominion Museum, Wellington, N.Z., in which he says :-

"I have reason to believe that some things recently purchased in London, made of bone and brought out here, are not genuine, and it is also quite true that a considerable number of bone relics of various kinds are manufactured in Auckland. So long as they are simply bought as curios by the ordinary tourist it does not matter so much, but, if they proceed to give them to museums and they take their place in the show-cases as specimens of Maori work, the matter is more serious. I lately had a visitor from Auckland who brought down a considerable number of most interesting specimens to sell to me. They were so well made that I must honestly confess I should have been deceived in at least two instances. The value of the collection was, at current prices, somewhere between $£ 40$ and $£ 50$. Fortunately the vendor left them with me for examination at my request, and I discovered ample proof that, although no exception could be taken to the method of the work or design or pattern from their general appearance, yet they were undoubtedly forgeries. I think it would be well if you were to insert the tenor of this letter in MAN, and more especially to point out that, so far as these bone and wooden curios are concerned, there is an infallible test. A very old 
and genuine-looking feeding funnel, which I wanted extremely and which had a splendid story attached to it as to how it was found in the draining of the Piako swamp, was put to this test and proved to be a forgery."

Mr. Hamilton, of course, refers only to the finer class of forgeries, which are capable of deceiving those conversant with Maori handiwork. But at a recent sale in London, out of the fifty or so lots there was only one genuine specimen; the others would not have deceived any ordinary collector interested in Maori work. Unfortunately there are many buyers who have no knowledge, and it is through them that these "fakes" get distributed about the country, finding their way into our local museums. It was only lately that I visited one of our most important museums in the west of England and was shown two such which had recently been purchased, and I am sorry to say at a very high figure. I hope that Mr. Hamilton's confession that he is capable of being deceived will make those who purchase New Zealand "curios" in this country all the more careful.

The foregoing communications refer to articles in wood, bone, and greenstone, but in the Journal of the Polynesian Society, Vol. VII, p. 244, there appeared an article by Mr. W. W. Smith on "spurious stone implements" mostly of a dark-coloured limestone in which the "polishing had undoubtedly been done with very fine emery " paper, which did not efface the coarser circular markings, on their flat faces and " sides, of the grindstone." The author points out that an examination by a strong lens revealed their mode of manufacture and apart from this their faces and sides were too flat, too level, and too broad at the part where they begin to bevel to the cutting edges. Instead of the neatly bevelled and polished cutting edge, as in old Maori implements of this class, the bevelling was flat.

From the evidence that we have now received on this subject it would appear that no class of New Zealand "curios" is exempt from the imitator's art. It resolves itself into a case of supply and demand.

J. EDGE-PARTINGTON.

\section{Australia.}

Brown.

\section{Marriage and Descent in North Australia. By A. R. Brown, M.A.}

In connection with certain work I recently found it necessary to go thoroughly into the question of the rules of descent in those Australian tribes which have eight matrimonial classes. Mr. R. H. Mathews, in a number of publications (e.g., Mas, $1908,83)$, has criticised the statement of Messrs. Spencer and Gillen that in the tribes having eight matrimonial classes, descent, so far as class is concerned, is in the male line. As I do not think that Mr. Mathews has stated the position quite clearly, I venture to raise the subject once more.

To illustrate the discussion it is necessary to use a simple diagram, such as the following, which represents the rules of descent in a tribe having the four-class system.

A, B, C, D represent the four classes. The sign $=$ means "marries," and may be read either way, that is, from left to right or from right to left. The arrows show the relation between the class of the mother and the class of her child, and may be read either up or down.

\section{Diagram I.}

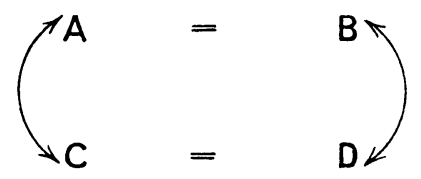

Thus, the rules of marriage and descent may be expressed as follows :-

A male marries $\mathrm{B}$ female and the children are $\mathrm{D}$.

\begin{tabular}{|c|c|c|c|c|c|}
\hline B & "ִ & A & , & " & , \\
\hline $\mathrm{C} \quad$, & " & D & , & " & " \\
\hline D $\quad$, & , & C & " & " & " \\
\hline
\end{tabular}

If we substitute for A Ipai, for B Kubbi, for C Kumbo, and for D Murri, the diagram illustrates the Kamilaroi system as given by Howitt. 